\title{
Политическое содержание информационной повестки дня социальных медиа
}

\author{
Дмитрий Каминченко
} В статье исследуется актуальная проблема политизации
общественной повестки дня с целью выявить
особенности политического содержания и место
политических тем в рамках общественной повестки дня.
Ключевые слова: информационная повестка дня,
медийная повестка дня, общественная повестка дня,
социальные медиа, информация.

(C) Каминченко Дмитрий Игоревич кандидат политических наук, ассистент кафедры прикладного политического анализа и моделирования Национального исследовательского Нижегородского государственного университета им. Н.И. Лобачевского

(г. Нижний Новгород, Россия), ertlfg2@rambler.ru

\section{Введение}

В современном обществе процесс установления информационной повестки дня приобрел особое значение. Активную роль в этом процессе по-прежнему играют политические субъекты и средства массовой информации. Кроме того, важнейшее значение имеет и социум, формирующий общественную повестку дня. В ней нередко присутствуют и политические темы, выражающие интересы различных политических субъектов или общественный запрос на участие в политическом процессе посредством обсуждения актуальных политических вопросов, а одним из наиболее значимых пространств ее формирования стали социальные медиа.

Вопрос изучения степени политизации общественной повестки дня, когда в ней в том или ином объеме присутствуют политические темы (предметный уровень), а также выражения определенной тональности различных аспектов этих тем (атрибутивный уровень), становится особенно важным в условиях современной информатизации. Анализ содержания политических тем, отраженных в общественной повестке дня, позволяет сделать выводы как о политических настроениях в обществе, так и о нормативно-ценностном содержании политического сознания индивидов. Фор- 
мулировка подобных выводов возможна, например, при анализе частоты проявления в повестке дня внутри - или внешнеполитических тем. Если в них преобладают внутриполитические темы, то могут вызывать интерес следующие вопросы: какие именно подтемы в ней отражены чаще остальных (государственное управление, избирательные кампании, гражданская и политическая активность и т.п.), какова тональность представленных в них направлений (в частности, по отношению к конкретным политическим акторам).

Цель данной статьи - проанализировать объем и содержание политической компоненты общественной повестки дня в коммуникативном пространстве социальных медиа в России.

\section{Теоретические основания}

В научном сообществе уделено немало внимания изучению социальных медиа в целом и их общественной и политической роли в частности. Согласно одному из наиболее часто цитируемых определений, сформулированному в работе Д. Бойд и Н. Эллисон (2008: 211), «платформы поддержки социальных сетей - это веб-сервисы, позволяющие индивидам создавать публичный или полупубличный профиль в рамках взаимосвязанной системы, формировать список других пользователей, с которыми он или она хотят поддерживать контакт, осуществлять просмотр и изменение своего списка связей и списков других пользователей в рамках данной системы». Как пишет С.Г. Ушкин (2017: 58), «новые медиа требуют не просто включенности в процесс потребления информации, но и определенных действий по ее поиску и фильтрации: подписаться на интересующие страницы, добавить в друзья известных людей, периодически следить за новостями и обмениваться мнениями, ставить лайки и делать репосты и т.п.». Изучение различных форм активности пользователей социальных медиа позволяет сделать выводы о существующих в обществе настроениях (в том числе политических), что подтверждает мнение о том, что коммуникативное пространство современных социальных медиа стало важным исследовательским полем для изучения общественной повестки дня и, в частности, степени отражения в ней отдельных политических тем (и их различных аспектов). В процессе изучения данной предметной области необходимо учитывать специфику сетевой организации социальных медиа, способную эффективно и гармонично сочетать индивидуализацию и децентрализацию с коллективными действиями.

Вопросы, связанные с информационной повесткой дня, также находятся в центре внимания ученых. Как отмечает С.С. Лушанкин (2017: 461), повестка дня включает в себя «наиболее важные вопросы, значимость которых установлена и подтверждена всеми либо большинством акторов». В науке выделяют несколько типов повесток дня: медиаповестка (состоит из таких компонентов, как доминирующие в СМИ темы публикаций), общественная повестка (ее составные элементы - важнейшие для большинства граждан проблемы), политическая повестка дня (включает первостепенные задачи для политических акторов) (Пономарев, 2010: 62). Различные типы информационных повесток дня взаимосвязаны и взаимообусловлены. Политические акторы стремятся оказывать активное влияние на формирование общественной повестки дня и отражение в ней их политических интересов и задач.

В коммуникативном пространстве социальных медиа формируется своя информационная повестка дня, которая по своему содержанию крайне близка общественной повестке и во многом пересекается с ней. Более того, повестка дня социальных медиа и общественная повестка дня зачастую могут быть настолько схожими 
между собой, что в качестве анализа общественной повестки допустимо проводить подобное изучение и для социальных медиа. Как подтверждение высказанного предположения выступает вывод, представленный в работе М. Шобера, Дж. Пасека, Л. Гуггенхейма, К. Лампе и Ф. Конрада (2016). Ученые отмечают, что, благодаря результатам анализа сообщений социальных медиа становится возможным предсказание результатов опросов по чувствительным темам вне зависимости от того, публиковали ли авторы (пользователи социальных медиа) когда-либо сообщения по данным вопросам (Schober, Pasek, Guggenheim, Lampe et al., 2016: 192). Таким образом, анализ текстов социальных медиа позволяет сформулировать выводы относительно содержания общественной повестки дня, выделив в ней определенные политические тематики (с возможностью их последующего подразделения на разные подтемы).

Отдельно отметим исследовательский интерес к изучению непосредственно политической повестки дня, а также к отражению различных политических тем и интересов в рамках общественной повестки. Д. Грин и Дж.П. Кросс (2017: 91), анализируя политическую повестку дня пленарных заседаний Европейского парламента, подчеркивают, что занимаемые членами Европарламента должности в рамках системы комитетов указанного института влияют на тот объем внимания, которые они уделяют той или иной теме. В одной из своих работ К. Грин-Педерсен и П.Б. Мортенсен (2010: 260) изучают такой тип политической повестки, как партийая система, которая, по мнению ученых, возникает в результате непрерывных политических обсуждений и дебатов среди политических партий. Разрабатывая модель, отражающую конкуренцию тематик в рамках формирования повестки дня партийной системы (на основе анализа данных политических практик в Дании), участие в которой принимают как правительственные, так и оппозицонные партии, ученые пришли к выводу, что оппозиционные партии в ходе проведения обсуждений и дебатов располагают большими возможностями для постоянной концентрации внимания на техтемах, которые дают преимущество именно им, в то время как правительственные партии вынуждены отвечать на те вопросы, которые подняты в рамках общей повестки партйиной системы (Green-Pedersen, Mortensen, 2010: 273).

Дж.Д. Виллалобос и К.В. Сирин (2012) рассматривают вопрос о влиянии президента на общественную и политическую повестки дня в рамках американской политической системы. Они обращают внимание на тенденцию, согласно которой публичные выступления президента, с одной стороны, помогают ему повлиять на общественное восприятие той или иной темы повестки дня как особо значимой, а с другой - подобный положительный эффект автоматически не трансформируется в повышение уровня общественной поддержки его деятельности по решению тех или иных вопросов в рамках этой темы (Villalobos, Sirin, 2012: 37). Б.Э. Конвэй (2013: 542), изучая воздействие атрибутивного уровня информационной повестки (связанного с тональностью различных аспектов сообщений) на общественное мнение на примере реформы здравоохранения в США, проводимой в период президенства Б. Обамы, делает вывод о том, что негативная тональность сообщений в СМИ о реформе здравоохранения оказала влияние на уровень общественной поддержки Закона о защите пациентов и доступной помощи (Patient Protection and Affordable Care Act (PPACA)).

Обобщая сложившиеся взгляды относительно особенностей процесса установления политической повестки дня, необходимо отметить, что этот процесс обусловлен по- 
литико-институциональным ландшафтом и распространенными практиками институционального взаимодействия, способными определять содержание повестки дня и принципы ее установления. Вместе с тем в условиях существующей конфигурации политические субъекты выбирают различные лингвосемантические инструменты и формы выражения, использование которых позволяет инкорпорировать ту или иную тему, ее конкретный аспект или идею в целом в содержание повестки дня. При этом важно подчеркнуть, что признание обществом продвигаемой в повестку дня политическим субъектом темы или ее отдельного аспекта как значимой для общества автоматически не подразумевает усиление поддержки этого политического субъекта в целом и его позиции по продвигаемому в повестку дня вопросу в частности. Указанная взаимосвязь требует отдельного и детального изучения. В рамках данной статьи проводится анализ политического содержания (на предметном (тематическом) уровне) общественной повестки дня в России на основе изучения социальных медиа.

\section{Методология}

Достижения обозначенной в исследовании цели подразумевает установление объема и выявление содержательных характеристик политической компоненты общественной повестки дня. Как уже отмечалось, ее анализ может быть осуществлен посредством изучения коммуникативного пространства социальных медиа. Исследование текстового массива социальных медиа позволяет сделать выводы о том, какие общественные и политические настроения существуют в данном коммуникативном пространстве, т.к. социальные медиа способны выступать проводником общественного мнения (Каминченко, 2016: 42) и представляют собой «один из важнейших институтов современного обще- ства, который способствует агрегации и артикуляции общественных интересов» (Балуев, Каминченко, 2017). Добавим, что нас в данном случае интересует предметный уровень информационной повестки дня (конкретные темы/подтемы), а не атрибутивный (тональность выражения отдельных тем/подтем).

Методологический инструментарий данного исследования включает применение контент-анализа, метода классификации и сравнительного анализа. Использование контент-анализа необходимо для изучения наиболее популярных и читаемых в социальных медиа текстов новостных сообщений различных СМИ, представленных в Интернете, что позволит выявить темы, составляющие общественную повестку дня в течение изучаемого периода времени. В качестве единицы проведения контент-анализа выбрана тема, а единицы счета - заголовки наиболее популярных в социальных медиа новостных сообщений. Заголовки новостей классифицированы по тематическому критерию, а темы в рамках политической рубрики - по содержательному: например, на внутрии внешнеполитические. Необходимо заметить, что один и тот же новостной заголовок может быть отнесен к разным категориям, что продиктовано многоаспектностью тематик анализируемых сообщений. Метод сравнительного анализа позволит соотнести популярность заголовков политических новостей с рейтингами новостных сообщений по другим темам. Он также позволит сравнить популярность внутри- и внешнеполитических тем в рамках общественной повестки дня.

\section{Результаты исследования}

Источник данных для проведения контент-анализа наиболее популярных в социальных медиа новостных заголовков агрегатор новостей MediaMetrics'. Наблюдение проводилось ежедневно в течение 
20 дней, с 10 по 29 июня 2019 г. после 21:00, т.к., на наш взгляд, к указанному времени информационная повестка дня зачастую уже установлена (анализировались только первые десять наиболее популярных новостных заголовков). Результаты представлены в таблице 1.

Таблица 1. Тематика новостных сообщений общественной повестки дня

\begin{tabular}{|l|c|}
\hline \multicolumn{1}{|c|}{$\begin{array}{c}\text { Тема новостных } \\
\text { заголовков }\end{array}$} & $\begin{array}{c}\text { Частота } \\
\text { встречаемости }\end{array}$ \\
\hline Происшествие & 92 \\
\hline Политика & 72 \\
\hline Культура & 20 \\
\hline $\begin{array}{l}\text { Социально- } \\
\text { экономическая сфера }\end{array}$ & 13 \\
\hline Туризм & 8 \\
\hline Здравоохранение & 3 \\
\hline Наука & 1 \\
\hline Военная сфера & 1 \\
\hline
\end{tabular}

Новостные заголовки политической тематики были распределены по разным подтемам: внутриполитическая (заголовки с тематикой внутренней политики Российской Федерации), внешнеполитическая (включает новости, связанные с отношениями России с зарубежными государствами) и мировая политика (отражаются темы взаимоотношений зарубежных государств). Результаты приведены в таблице 2 .

Таблица 2. Политическое содержание общественной повестки дня

\begin{tabular}{|l|c|}
\hline $\begin{array}{c}\text { Тема новостных } \\
\text { заголовков }\end{array}$ & $\begin{array}{c}\text { Частота } \\
\text { встречаемости }\end{array}$ \\
\hline Внешняя политика & 40 \\
\hline Мировой политика & 18 \\
\hline Внутренняя политика & 14 \\
\hline
\end{tabular}

В новостных сообщениях, относящихся к внешнеполитической сфере, чаще остальных встречались слова об отношениях России с Грузией (16 сообщений), Украиной и США (по 6 сообщений). В заголовках новостей из области мировой политики доминируют тексты, посвященные Украине (16 сообщений), Германии (6), EC (4). В рамках новостной тематики, посвященной внутриполитической сфере, встречаются заголовки по таким темам, как права человека, общественные настроения, работа представительных органов власти, прямой диалог власти и общества и т.д.

\section{Заключение}

По итогам проведения контент-анализа и классификации наиболее популярных среди пользователей социальных медиа тематик новостных сообщений различных СМИ, представленных в Интернете, можно сделать ряд выводов.

Во-первых, во всем проанализированном текстовом массиве представлен широкий тематический спектр (происшествия, политическая, культурная, социально-экономическая, туристическая, научная и военная сферы, а также здравоохранение). Это может свидетельствовать о том, что тематически информационная повестка дня социальных медиа (а на их основе и общественная) весьма разнообразна (что, в свою очередь, поднимает вопрос о фрагментарности современной повестки дня), однако в повестке дня социальных медиа преобладает тематика, связанная с происшествиями.

Во-вторых, переходя непосредственно к политической тематике сообщений, нужно обратить внимание на тот факт, что она в новостных заголовках занимает второе место со значительным отрывом от последующих по популярности тем, что свидетельствует о востребованности политической тематики в российском обществе. 
В-третьих, говоря о политической тематике наиболее популярных и читаемых среди пользователей социальных медиа новостных сообщений, необходимо указать на наличие в ней предметного разнообразия. Всю совокупность текстового массива новостных сообщений, связанных с политической областью, мы подразделили на три группы: внешнеполитическая и внутриполитическая сферы и мировая политика. Самыми популярными в социальных медиа применительно к политической тематике являются заголовки новостных сообщений о внешней политике России. Второе место в этой подгруппе занимают новостные заголовки по теме мировой политики, третье - о внутриполитической тематике.

B-четвертых, отметим, что применительно к содержанию новостных заголовков в рамках внешнеполитической тематики в них чаще всего говорится об отношениях России со странами ближнего зарубежья (Грузия и Украина) и с США. Украина больше, чем другие государства, представлена в новостных заголовках из блока тем по мировой политике. Гораздо реже упоминаются Германия и ЕС. Таким образом, можно сделать вывод о том, что в рамках внешнеполитической тематики и темы ми- ровой политики лидирующие позиции в наиболее популярных в социальных медиа новостных заголовках занимают государства ближнего зарубежья.

B-пятых, говоря о популярных в социальных медиа новостных заголовках внутриполитического блока, необходимо обратить внимание на присутствие как тем, относящихся к сфере общественных активности и настроений, так и тем, связанных с функционированием органов государственной власти и с их взаимодействием с обществом.

Таким образом, в общественной повестке дня в рассматриваемый период времени наблюдается высокий уровень содержания политических тем, что свидетельствует об интересе общества к данной области. Причем, можно говорить о разнообразии и многоаспектности политического содержания общественной повестки дня. В связи с этим тема политического содержания общественной повестки дня, безусловно, требует дальнейшего изучения, например, проведения мониторинга в разные временные периоды, что позволило бы установить динамику изменения популярности политической тематики (в рамках общественной повестки дня) в целом и ее отдельных подтем или аспектов в частности.

\section{Примечания}

${ }^{1}$ Официальный сайт MediaMetrics. Режим доступа: https://mediametrics.ru/rating/ ru/online.html (дата обращения: 01.07.2019).

\section{Библиография}

Балуев Д.Г., Каминченко Д.И. Отражение ценностей современного российского общества в социальных медиа // Вестн. Пермск. ун-та. Сер.: Политология. 2017. № 3. C. 5-13.

Каминченко Д.И. Порядок как ценность в текстах современных социальных медиа // Информационное общество. 2016. № 2. С. 39-42.

Лушанкин С.С. Категория «повестка дня» в структуре политического процесса: понятие «политической повестки дня» и модели ее формирования // Вестн. Удмуртск. ун-та. Сер.: Социология. Политология. Международные отношения. 2017. Т. 1. № 4. C. 456-465. 
Пономарев Н.Ф. Фрейминг медиаповестки дня и типология медиафреймов // Вестн. Пермск. ун-та. Сер.: Российская и зарубежная филология. 2010. № 3 (9). С. 62-69.

Ушкин С.Г. Кофейни, джентльменские клубы и социальные сети, или Где сегодня формируется общественное мнение // Мониторинг общественного мнения: экономические и социальные перемены. 2017. № 6 (142). С. 52-62.

Boyd D., Ellison N.(2008) Social Network Sites: Definition, History and Scholarship. Journal of Computer-Mediated Communiuction. 13: 210-230.

Conway B.A. (2013) Addressing the "Medical Malady": Second-Level Agenda Setting and Public Approval of "Obamacare". International Journal of Public Opinion Research. 25 (4): 535-546. Режим доступа: https://doi.org/10.1093/ijpor/eds041 (дата обращения: 01.07.2019).

Green D., Cross J.P. (2017) Exploring the Political Agenda of the European Parliament Using a Dynamic Topic Modeling Approach. Political Analysis. 25 (1): 77-94.

Green-Pedersen C., Mortensen P.B. (2010) Who Sets the Agenda and Who Responds to It in the Danish Parliament? A New Model of Issue Competition and Agenda-Setting. European Journal of Political Research. 49 (2): 257-281. DOI: 10.1111/j.1475-6765.2009.01897.x

Schober M., Pasek J., Guggenheim L., Lampe C. et al. (2016) Research Synthesis. Social Media Analyses for Social Measurement. Public Opinion Quarterly. 80 (1): 180-211.

Villalobos J.D., Sirin C.V. (2012) Agenda Setting from the Oval Office: An Experimental Examination of Presidential Influence over the Public Agenda. International Journal of Public Opinion Research. 24 (1): 21-41. DOI: 10.1093/ijpor/edr017 